\title{
Synergetic effects of network interconnections in the conditions of virtual reality
}

\section{Kateryna Kraus ${ }^{1}$ (D), Nataliia Kraus² (iD, Olena Shtepa ${ }^{3}$ iD}

\begin{abstract}
PURPOSE: The disclosure of the content of the synergetic effect, as a result of network interactions of development institutions in a new economic virtual reality, and the presentation of the general characteristics of their relationships through knowledge of the functioning of clusters, which in the XXI century occurs during the digitalization of the economy, resulting in digital products/services and various platforms. METHODOLOGY: On the basis of dialectical, systemic and matrix methods and using the institutional-network approach, the characteristic features of network interactions of cluster formations in the conditions of virtual reality are studied, which are becoming the norm today, a good quality and effective rule for the practical implementation of various sectors of the economy in the course of digitalization of the economy. The method of comparison is used in terms of conditions for the formation of an innovation-digital cluster from the standpoint of the theory of institutionalism. FINDINGS: Network cooperation in the conditions of virtual reality demonstrates synergetic effects through new forms of qualitative accumulation and an increase of new knowledge, which occur through their network replication (division), and innovative growth is the result of the formation in the economy and society of a new, network model of coordination of connections, network cooperation of new quality, constantly adjusted by digital tools. The synergistic effect of networking creates a new phenomenon of growing marginal utility and growing marginal productivity from innovative glocalization and digital globalization. The greater the scale of innovation

1 Kraus Kateryna, Ph.D. (Economics), Associate Professor, Senior Lecturer of the Department of Management, Borys Grinchenko Kyiv University, 18/2 Bulvarno-Kudriavska Str, 04053, Kyiv, Ukraine, e-mail: k.kraus@kubg.edu.ua (ORCID: htttp://orcid.org/0000-0003-4910-8330).

2 Kraus Nataliia, Dr. Sc. (Economics), Associate Professor, Professor of the Department of Finance and Economics, Borys Grinchenko Kyiv University, 18/2 Bulvarno-Kudriavska Str, 04053, Kyiv, Ukraine, e-mail: n.kraus@kubg.edu.ua (ORCID: htttp://orcid.org/0000-0001-8610-3980).

3 Shtepa Olena, Ph.D. (Economics), Associate Professor, Senior Lecturer of the Department of Management Borys, Grinchenko Kyiv University, 18/2 Bulvarno-Kudriavska Str, 04053, Kyiv, Ukraine, e-mail: o.shtepa@kubg.edu.ua (corresponding author) (ORCID: htttp://orcid.org/ORCID 0000-0003-2220-2052).
\end{abstract}


and digital activities is in the conditions of virtual reality, the greater the efficiency is of the use of additional resources. The effect of scale is especially pronounced within the network, which uses the standards produced and tested by it. IMPLICATIONS FOR THEORY AND PRACTICE: It is proved that the synergetic approach used in the formation and development of innovation-digital clusters is considered through the prism of the relationship "subject - subjective relationship of innovation-active organizations and digital enterprises." In addition, in our case, this effect lies in the plane of restructuring the "old" development institutions in the "new", under the influence of the relevant institutional and legal basis, systemic and comprehensive modernization and diversification of all sectors of production, improvement of the innovation and investment situation, construction of effective innovation and digital virtual-real infrastructure of the European standard, implementation of clustering of the economy using the opportunities of network cooperation.. ORIGINALITY AND VALUE: The content of a virtual slice of network interaction of cluster formations in the conditions of virtual reality offered by the authors is revealed; the authors' vision of its structural elements is given, as from a digital network augmented and virtual socio-economic reality; the taxonomy and categorization of terminology with the help of which it is possible to reveal the formation of network cooperation in the conditions of virtual reality and its further development are investigated; on the basis of the conducted deep theoretical and methodological analysis and the presentation of a retrospective of innovation and digital changes, a step-by-step transformation of cluster formations is shown. The basis of network economy is network institutions, entities, organizations, in addition, it forms an environment in which any business entity or individual, which, no matter where it is in the economic system, has been able to communicate easily and at minimal cost with any other company or individual about working together, trading issues, or know-how, or just for fun in the conditions of the new virtual reality.

Keywords: virtual reality, network economy, network cooperation, cluster formations, augmented reality, synergetic effects, digitalization of the economy, cluster network structures, quality of network interconnections

\section{INTRODUCTION}

Given the existing scientific developments in the field of knowledge of network economics, what have remained unexplored are the qualitative transformation of network relationships, new conditions for the formation of innovation-digital clusters and cooperation of clusters in virtual reality, in order to obtain a synergistic effect based on innovative changes in activities at all levels of economic aggregation in the direction of the formation of Industry 4.0. The practical side of universal functions is not fully disclosed, which are inherent in all subjects of cluster formations, namely: regulatory; integrative; broadcasting; communicative (this feature has its own feature - informal 
communication); consolidation and reproduction of public relations on the basis of virtual-real network interconnections.

The era of the network economy, which manifested itself in the transition to the third millennium, affected all aspects of economic and social life. Global development of the network economy can be seen as expanding the base of post-industrial society. This allows us to characterize confidently the processes taking place in the global economy and the world community as a manifestation of a "paradigm shift." Modern civilization is characterized by a sharp increase in the dynamism of socio-economic spheres of life and the growth of risks, uncertainty in the development of all aspects of society, and the formation of virtual reality. This state of affairs in the world is called the "era of turbulence."

Institutionally, the complication of the formation of both network and innovation, digital, virtual economies is associated with the emergence of a new method of coordination and harmonization of interests. Thus, in the industrial age (industrial paradigm) the world community was based on two ways of coordination: a hierarchical order with a system of vertical subordination and a center of administrative management (rigid model of coordination); and a market system with price signals, as some deviation from the rigid and clear hierarchy (flexible, but quite atomistic). The postindustrial paradigm is characterized by a non-hierarchical order or the socalled network coordination mechanism. The world economy and all its subsystems are stratified into cluster-network structures with horizontal connections and a collaboration mechanism (hybrid model - flexible and integrated at the same time).

\section{LITERATURE REVIEW}

In recent decades, the idea of creating clusters based on networking and quality cooperation within this type of entity has found its application in virtually all countries, including not only the EU, USA, Japan, but also South America, Eastern Europe, and Africa. Today, the cluster model, filled with quality network connections, is characterized by a high synergy effect and is one of the most effective forms of achieving competitive advantage. The concepts of creating clusters are quite diverse. Yes, in Canada, Spain, Germany - this is an innovation system; in Austria, Belgium, the Netherlands, Norway, the USA, Switzerland - production and innovation networks and their interaction on the basis of cooperation; in Denmark - resource zones; in Italy, Finland - intersectoral flows of knowledge; in the UK - regional innovation systems. 
The creation and consolidation of such development institutions through government programs are specific to Argentina, Chile, and Canada. Effective functioning of network platforms is typical of Belgium, France, South Africa, Switzerland (through the interaction of research centers), Colombia, Poland, Portugal, Argentina, Australia, Germany (through public-private partnership), Denmark, Spain (interaction within industries networks). Internationalization based on the program of competitiveness clusters is inherent in the economies of Japan, Ireland, and Austria. The process of knowledge-based clustering is observed in Israel, Great Britain, Germany, Ireland, Finland, Estonia, Spain, the Czech Republic, Austria, Poland (OECD, 2014; OECD, 2012).

In Ukraine, economic network cluster formation occurs mainly spontaneously, under the influence of market forces. This influence is quite natural but theoretical, methodological, and applied aspects are not fully realized. The theory of management of such formations, regulation of the process of their creation and functioning has not been properly developed in the economic science and practice of Ukraine, and unadopted application of foreign experience does not provide the desired effect in the socio-economic and institutional conditions of the country.

The current institutional structure of Ukraine's economy does not meet new challenges of economic transformation due to significant systemic contradictions caused by the low adaptation to modern market realities of institutions, as well as a weak ability to participate actively in the reproduction process of institutions generated by transformational change (Holian, 2006).

Names of foreign scientists (Boudeville, 1966; Boshchma, 2005; Richardson, 1973; Richardson, 1974; Porter, 2005; Perroux, 1950, 1967; Spilling, 2006; Winter, 1984; Chesbrough, 2007) are connected with the study of general aspects of structural restructuring and complex modernization of the economy in the direction of its regional network and innovative clustering. Well-known researchers (Andriichuk, 2010; Androschuk, 2009; Britchenko, 2019; Gareev, 2012; Deliia, 2011; Dombrovskyi, 2011; Zhdanova, 2008; Karetin, 2009; Katukov, 2012; Kraus, 2019, 2018; Kryvoruchko, 2018; Lukianenko, 2008; Napolskikh, 2012; Prigochin, 2005; Pishulin, 2020; Odyagailo, 2006; Ratner, 2011; Tatarkin, 2011; Togunov, 2009; Tishchenko, 2010; Usov, 2009; Haken, 2005; Fedorov, 2010) have dealt with the formation of virtual reality in the world, innovative modernization, its strategic guidelines and mechanisms for their implementation, structural modeling of the institutional environment of the innovation cluster, self-organization as a new methodology for studying economic systems, and economic development of regions. (Zaremskyi, 2010; Ivanov, 2013) were engaged in the development and implementation of the cluster strategy of innovative development of regions in the context of global economy, and clarification of 
the social context of innovative development. But many issues, such as the formation of clusters in virtual reality and the formation of a quality network economy in global digital space, the development of network relationships and cooperation, remain insufficiently disclosed.

The work of NAAS academics is devoted to theoretical principles of clustering (Sabluk, \& Kropyvko, 2010), as well as foreign researchers (Enright, 1992; Cappellin, 2003; Cappellin, 2007; Cooke, 2006; Cooke, \& Martin, 2006; Rallet, \& Torre, 2001; Owen-Smith, \& Powell, 2004; Lagendijk, \& Oinas, 2005). Another researcher proposed a conceptual approach to cluster organization, and substantiated the conditions for the formation and effective functioning of clusters (Kropyvko, 2010). In a number of scientific papers (Mazniev, 2015; OESD, 2003; Cooke, 2006; Cooke, \& Martin, 2006) in different periods, it was argued that cluster theory in modern conditions is developing not only on the theory of competitive advantage, but also using the achievements of synergetics, logistics, homeostatics, and other scientific concepts.

But many issues, such as the formation of clusters in virtual reality and the formation of a quality network economy in general within global digital space, the development of network relationships and cooperation, remain insufficiently disclosed. Based on the generalization of literature sources, experience and own research, based on system-synergetic positions and using a logistical approach, the authors' aim is to achieve a synergy in virtual reality through the network interaction in clusters. To present a visualization of the model of creation and effective functioning of innovation clusters.

In order to form an innovative cluster complex on the basis of the cluster approach, it is necessary to consider, first of all, the existing methodological approaches to cluster identification proposed by foreign and domestic scientists. The most well known should be considered the methodology for the allocation of clusters (Porter, 2005), which includes three stages:

1) The composition of the cluster is determined, namely: first, the core of the cluster is detected - a large company or group of similar; secondly, there is a building of vertical links between the core and related companies; third, main horizontal relationships are formed relative to the core of the cluster, for this purpose, the production involved through common channels or those that create by-products or services are identified; and on the basis of determining the use of common factors of production, supply, technology, etc., additional horizontal links are established.

2) The composition of organizations within the cluster that provide specialized services, technologies, information, capital, and infrastructure is determined.

3) Power structures, legislative institutions that have an impact on the activities of the cluster are identified. 
Porter (2005) also developed the so-called "competitive diamond" or "diamond" to determine national preferences. We share the conceptual approaches of research to the basic features of clusters and their typification (Fedorenko, Tugay, Goyko, \& Dzhabeylo, 2008). These methods contain only a qualitative analysis of the preconditions for the formation of an industrial complex based on a cluster approach. A number of domestic researchers suggest the use of quantitative analysis to determine the directions of cluster formation. One of such directions is the calculation of coefficients of localization and specialization of regions (Dlugopolskyi, 2003).

Another analytical approach to cluster identification (Tarasova, 2007) is based on the calculation of coefficients that are divided into groups. In particular, the level of specialization of the region's economy, the level of development of small and medium enterprises, the level of development of investment activities, the level of imports (exports) in the region's economy. In our opinion, for the formation of networks of innovation clusters it is most appropriate to apply an approach that uses a comprehensive assessment. In addition, at the present stage of development of innovation clusters, it is necessary to apply an approach that can not only take into account the sectoral characteristics of operating activities but also their impact on the formation of market segments of national economy and the interests of all participants.

\section{METHODOLOGY AND RESEARCH METHODS}

The aim is to disclose the content of the synergetic effect as a result of network interactions of development institutions in new economic virtual reality and present the general characteristics of their relationships through knowledge of the functioning of clusters, which in the XXI century occurs during the digitalization of the economy, which results in digital products/ services and various platforms. The objectives of the study are: to reveal proposed by authors the content of virtual slice of network interaction of cluster formations in terms of virtual reality; to offer the authors' vision of its structural elements, both from a digital network augmented and virtual socioeconomic reality; to study the systematics and categorization of terminology, which can be used to identify the formation of network cooperation in virtual reality and its further development; on the basis of the conducted deep theoretical and methodological analysis and presentation of a retrospective of innovation and digital changes to show the step-by-step transformation of cluster formations in the section: formation of a network of informal and formal relations between economic agents; plurality of economic agents; territorial concentration; high-quality specialization; common institutional, 
socio-economic, virtual-economic environment; using a synergetic approach to consider innovation-digital clusters through the prism of the relationship "subject - the subjective relationship of innovation-active organizations and digital enterprises".

During the writing of the article, general and special research methods were used, namely methods of deduction and induction, methods of synthesis and analysis, unity of historical and logical in clarifying the essence and role of clusters and mechanisms of coordination of interests of cluster interaction, based on a new format of network relationships in virtual reality. On the basis of dialectical, systemic and matrix methods and using the institutionalnetwork approach, the characteristic features of network interactions of cluster formations in the conditions of virtual reality are studied, which are becoming the norm today, a good quality and effective rule for the practical implementation of various sectors of the economy in the course of digitalization of the economy. The method of comparison is used in terms of conditions for the formation of innovation-digital cluster from the standpoint of the theory of institutionalism. The method of grouping and generalization is applied to studying the experience of functioning and development of innovation clusters in Ukraine, and also innovative-digital hubs. Some statistical data on advanced technologies by types of activity produced by Ukrainian clusters are presented and an empirical analysis of network relationships between educational institutions, enterprises, research institutions, customers, suppliers of equipment, materials, components, software. A process and system approach was used in the formation of practical recommendations in terms of enhancing synergetic effects as a result of new quality of interaction of all participants in cluster systems in virtual reality.

\section{RESULTS AND DISCUSSION}

The representative of the institutional-sociological school in France, economist Fransua Perroux in 1950, proposed the theory of growth poles (Perroux, 1950; Perroux, 1967), which is based on the idea of the leading role of the sectoral structure of the economy and, above all, the leading industries that create new goods and services. According to him, all economic entities are unequal at the initial stage of relations, connected by subcontracting relations, which are formed naturally. Once in a polarized space, a networked firm must take into account direct and indirect coercion from the dominant unit, that is, economic units no longer behave as interdependent partners, but as part of a single system, a network. 
Jean-Francois Perrault proved that the formation of poles of economic growth occurs in the locations of enterprises of dynamically developing industries. Such industries become the "poles of attraction" of factors of production, which leads to the emergence and growth of industrial centers, the emergence of a synergistic effect of network interconnections. This theory laid the foundations for regional programs in many countries around the world on the basis of network cooperation.

The ideas of Jean-Francois Perrault were developed by the French scientist Jake Boudeville (Boudeville, 1966). He gave a regional aspect to the economic category of "growth poles", distinguishing three types of economic spaces: homogeneous, polarized, and planned. The underdeveloped territory has a homogeneous appearance of space, but during the development of network connections the space inevitably becomes polarized. For Jake Boudeville, not every regional center is a pole of growth, but only one in which propulsive industries have developed. This theory of economic development of the region determines the search for industries that will give impetus to the development of the entire regional system with its network connections. In his research, the scientist showed that the poles of growth could be considered not only a set of leading industries, but also specific areas (settlements), which perform in a country's economy as a source of innovation and progress.

The scientific works of English researcher Henri Richardson (Richardson, 1973; Richardson, 1974) are devoted to the ideas of the formation of accumulated cities, which become large industrial centers, a kind of poles of growth. This stimulates technical progress and productivity growth, has a significant impact on network processes, and the location of enterprises. In addition to the energy effect of the agglomeration and the personal preferences and preferences of investors, key elements of regional growth in the model of Henri Richardson are technical progress and socio-political component. In essence, Henri Richardson's model realizes the same functional relationships that are characteristic of models of the neoclassical school between the rate of growth and the rate of capital accumulation, increasing labor supply and the speed of technological progress. The functions of the studied model depend on the effect of agglomeration, the advantages of localization, networking and branching of cooperation, the difference in factor prices in the region and in the country as a whole, and other features of the regions (Richardson, 1974; Kuznetsova, 2002).

American economist Sidney Winter (Winter, 1984) in his research identified two technological modes in which an innovative company operates, namely: routine and entrepreneurial. Entrepreneurial regime is characterized by high technological capabilities - investment in innovation can lead to tangible success. At the same time, this success is not guaranteed. 
The regime is characterized by a significant variety of ideas and a large network of firms operating in it (medium, small), which are based on more applied and hidden knowledge than on the results of research protected by patents. The entrepreneurial regime is characterized by a low level of cumulativeness, the main type of evolution is an industry or cluster, and the main metaphor is "expansion."

In a routine mode, main actors are large firms. Technological opportunities in it are small, but at the same time, there is a high probability of incremental innovations as a result of research. The mode is characterized by high cumulative qualities, due to which the barriers to entry are quite high. Patents that protect the results of scientific developments are an important condition for the assignment of innovative rent. Knowledge in a routine mode is highly specific and less accessible. The primary type of cluster (or branch) evolution is "creative accumulation," and the main metaphor is "deepening" (Panyushkin, 2011, p. 59; Spilling, 2006).

In his work "Open innovations. Creating Profitable Technologies" (Chesbrough, 2007), Professor Henry Chesbrough of the University of California proposed a paradigm of closed and open innovation. He calls new approaches to effective innovation "open innovation", understanding that in managing innovation processes, organizations should not be "closed" in the internal environment, and it is necessary to build network relationships and interact. Comparing the features of innovation, which is carried out on the principles of openness and closedness, the scientist demonstrates the contrast of old and new approaches to the development and implementation of innovations.

Along with a comparative description of the old foundations and new, including network, approaches to the implementation of innovations, Henry Chesbrough provides a scheme of open and closed innovations, which has become world famous. The author uses the tunnel to describe the innovation process, the continuous and intermittent boundaries, which clearly demonstrate the essence of yesterday and today's foundations of open networking. According to the author, today's business enters a new stage of innovation, when the sources of innovation potential of companies lie in the plane of synergetic effects as a result of network cooperation (Chesbrough, 2007; Trifilova, 2008, p. 73). Open innovations are a new structure of organization of innovation processes, moving them abroad into an open, free field of high technology transfers through network interactions, and new organizational forms of integration of knowledge-intensive commercialized technologies that work in global markets (Fedorov, 2010, p. 117).

Exploring the models of open and closed innovations, Henry Chesbrough paid special attention to the following question: How, without the help of central laboratories of industrial enterprises (which were key to innovation in 
the past), will there be a diffusion of technologies suppliers, consumers, and industry consortia? Closing itself in the internal environment, and not being a member of network formations, the company spends only its resources, duplicating innovative developments. Hiding the results of research, organizations do not make a profit, unlike those companies that allow other businesses to use their own technology (Trifilova, 2008, p. 74).

Unused innovations lose their appeal and relevance over time. Henry Chesbrough calls the principle extended to the period of closed innovations (when companies preferred to "put" unused technologies on the "shelf") "naphthalene." In his opinion, today it is impossible to treat the ideas and people who created them as "warehouse stocks of the company." The big risk threatens those who postpone the implementation of developments "until better times for business" and is that they can once and for all lose people and innovative ideas that they have developed for the company (Trifilova, 2008, p. 75).

Having studied entropy (from the Greek - "turn," "transformation") as a tool for analyzing innovation and considering through the prism of entropy to predict its effectiveness, the Russian professor Leonid Usov proposed his concept (Usov, 2009, p. 38). The entropy of stability of production systems should show the main consequences of economic activity. In this sense, Leonid Usov understands changes in the entropy of production systems as the main criterion of network efficiency of innovation. He pointed to three qualities of entropy as a tool for analyzing innovation, namely: in closed systems, entropy is constantly increasing; increasing entropy means eliminating differences; the more freedom, the greater the entropy.

These qualities of entropy partially reveal the paradigms of closed and open innovations by Henry Chesbrough. According to the concept of Leonid Usov, in an open system, which is filled with network connections, there is, first, its own entropy, which, as in closed systems, always grows. Second, entropy penetrates an open system from the environment (imported entropy). Third, from the open system, entropy moves to the external environment, where high quality, inter-corporate relationships are very valuable and bring increased profits (Usov, 2009, p. 39).

Examining the genesis of the formation of the theory of innovation, one cannot ignore the emergence of the theory of self-organization (Illia Prigochin, 2005) and synergetics (Herman Haken, 2005). According to the theory of self-organization, innovation-digital activity is provided only under the condition of high flexibility of structure in modern conditions of virtual reality. For this reason, the self-organization of the network economy system begins with the formation of a structure in which each source of external impulses corresponds to an element that generates internal innovation 
and digital products/services. At the next stage, the system evolves in the direction of a more orderly state, which is achieved under the influence of the struggle for existence. An additional hierarchical level is formed, at which the feedback loop with the external environment is closed (Deliia, 2011, p. 17).

The triple helix model of Professor Henri Etzkowitz of Stanford University is an example of a harmonious combination of organization and self-organization in innovation processes in network systems. The state, by determining the "rules of the game" of economic entities, supporting institutional transformations, exerts influence on the innovation process. "Business, academic universities and institutes, interacting with each other in the process of generation and commercialization of innovations, show an example of self-organization" (Erokhina, 2011, p. 79-80).

Institutional transformations form a "critical mass" in public opinion to understand the need for large-scale modernization of social order in the direction of the network economy or its important subsystems, and especially innovation (Tatarkin, 2011, p. 16). Modernization is an ongoing process of expanding the opportunities of socio-economic and general social development using new and updated institutions and forms (relationships) between actors, including network. This type of modernization is called and qualified as institutional (point, local, limited), which is a prerequisite for bringing macroeconomic and other non-modernized institutions and forms in line with the needs of a particular stage of social development.

The complex and systemic nature of modernization provides a consistent solution to problems of socio-economic development that hinder the formation of the network economy in Ukraine. Modernization of the economy will not be effective and complete without changes in political, social, and environmental spheres. You can increase and develop innovative developments as much as you want, but if you do not create an innovative network environment, the effect of innovation will happen in other countries, where this environment is formed and is operated (Tatarkin, 2011, p. 17).

The resumption of economic growth, which is being pursued in power structures and production circles, now requires active mastery of its national innovative path of development. Ensuring the transition to an innovative type of development is a prerequisite for preserving the economic and political sovereignty of Ukraine. It is generally accepted that an economy characterized by a high level of resource and energy consumption of its products, which is typical for Ukraine, even without the influence of external factors is doomed to gradually deplete the reserves of extensive growth and further increase the threat of economic depression. Therefore, the implementation of the synergetic effect of innovative development, based on network cooperation, 
becomes for Ukraine the only way to reduce the technological and economic lag behind developed countries (Andriichuk, 2010, p. 4).

The process of economic agglomeration of interconnected enterprises in a separate territory has been known since the time of handicraft production. Beginning in the 1980's, it received a new impetus in the form of the development of network formations, clusters, as an important factor in the economic growth of the region. Today, it can be stated that regions where clusters are emerging are becoming leaders in economic growth. Such leading regions determine the competitiveness not only of regions but also of national economy. The increase in research in this area suggests that the geographical proximity of the relevant economic areas contributes to a higher level of capital use and innovation. Development institutions, which are in direct contact with end users, suppliers, research laboratories, educational institutions, form important factors in the development of regional and national economies (Karetin, 2009, p. 320).

Network economics is a form of information and communication in the digital economy. Network economy is an economy in which activities are carried out through electronic networks. The basis of a network economy is network entities and organizations. However, the network economy creates an environment in which any business entity or individual, no matter where it is in the economic system, has been able to communicate easily and at minimal cost with any other company or individual about working together, exchanging ideas, trade issues, or know-how, or just for fun.

The formation of a network society and network economy (mesh economy) lies in the plane of the emergence of new, more flexible means of managing companies and communities, complemented by the development of network technologies and spread of solutions based on blockchain technology (chain of transaction blocks). The network company provides for the elimination of various intermediaries in the registration or accounting of property rights to any property, as well as in the conclusion of any agreements with tangible or intangible assets. This leads to colossal changes in the state and corporate bureaucracy, as well as to full-scale democratization of the financial sector (Pishulin, 2020, p. 41).

From the point of view of the institutional-network approach, a cluster is a new form of organization - a heterarchy that has no pronounced hierarchical features and is only partially a market, characterized by organizational heterogeneity. Such a structure is a network that operates on the basis of institutional mechanisms of coordination and cooperation. Its formation presupposes stable connections between participants due to various reasons, including both geographical proximity and the presence of institutions, the 
interaction with which is not always, and in some cases is partially, regulated by the market (Tishchenko, 2010, p. 74).

Among key factors that shape the institutional environment of the territory are: improving regional and municipal regulatory frameworks for innovation policy; investment and economic climate and image of the region; efficiency of the system of regional and local government bodies, competence of the management; mentality of the population, innovative culture of entrepreneurs, traditions and habits of the local scientific community; the level of development of informal development institutions, communication channels and innovative, digital virtual-real platforms for cooperation (Napolskikh, 2012, p. 43; Kryvoruchko, 2018, p. 30).

Clusters were studied in detail by Michael Porter in the 1980's. The approach used by the scientist is called the classical liberal or Anglo-Saxon approach. This approach is based on the self-organization of economic agents within the mechanisms of a free market in the absence of direct state intervention. The Modern European approach emerged in France in 2008. It is called the "pole of competitiveness" and is based on a partnership of business, central and local government. The government is a stakeholder in the global competitiveness of the whole country and in achieving the "pole of competitiveness" at a world level, which is expressed through various forms of state support (Napolskikh, 2012, p. 42).

Michael Porter's research attention is objectively focused on the phenomenon of "cluster," as a group of geographically close interconnected companies and, through different types of networks, organizations connected with them, operating in a particular area and characterized by common activities and complementarity. The cluster, as a new model of enterprise integration, allows competitive advantages to be obtained from a combination of factors such as geographical location, interaction, specialization, innovation, and networking. According to Michael Porter, "clusters use important connections, complementarity of industries, dissemination of technologies, experience, information, marketing better than industries... Cluster is not a technology park, not a business incubator, not an industrial park and not a free economic zone - it would not be correct to say that a cluster is a territorial production complex or a research and production association. However, the elements of infrastructure that exist today, or newly created elements of infrastructure, can be part of clusters..." (Porter, 2005, p. 265).

Nowadays, there are many approaches to understanding the essence of cluster. We agree with the opinion of Russian scientist Serhii Karetin, who emphasizes that clusters are concentrated by geographical groups of interconnected companies, specialized service providers, firms in relevant fields, as well as organizations related to their activities (universities, 
standardization agencies, trade associations) in certain industries that compete but carry out their work (Karetin, 2009, p. 320).

In our opinion, it should be added to the above definition that innovation clusters are vertically integrated structures that are designed to produce competitive innovative products, using the unrealized internal potential of the region, ensuring the connection of production with the spread of new technologies and innovations.

Economic relationships within the cluster create new opportunities for production development, its innovative renewal. Enterprises in the cluster in the process of interaction and "convergence" of interests, gradually overcome disunity, inertia and isolation on internal problems, which positively affects the growth of their technical level and competitiveness of products (Zhdanova, 2008 , p. 268). This allows the cluster to obtain a potential that exceeds the sum of its potential of individual structural components (economic agents) and allows innovation enterprises to carry out digital, investment, and innovation activities stably (Tishchenko, 2010, p. 76).

Modern clusters, uniting a significant number of formally independent enterprises and social institutions, act as a single economic entity. Clusters are an environment for the formation of an innovative approach to public and corporate governance. The purpose of the state cluster innovation policy should be to increase the competitiveness of territorial economic systems, and competitiveness factors - components of the so-called "Cluster Complex" - "4C" (by analogy with the "Marketing Complex" - "4P") (Napolskikh, 2012, p. 41).

Foreign scientist Dmytro Napolskykh considers that the "Cluster Complex" - " $4 \mathrm{C}$ " refers to concentration, competition, cooperation, competitiveness. Another foreign researcher, Timur Gareev (Gareev, 2012, p. 12), proposes that the cluster complex should be considered through its five typical characteristics, and accordingly calls it " $5 C$ ", namely:

- Concentration (geographical concentration of organizations that form a cluster portfolio);

- Competition (competitive basis of a general type of economic activity and competition between firms, i.e. the creation of a dynamic network of domestic market suppliers);

- Cooperation of firms horizontally and vertically and the formation of a specialized economic and market infrastructure around the cooperative firms;

- Communication (information, including advertising strategy) common with the external environment;

- Competence of human capital in a portfolio sphere of the cluster. 
Ukrainian scientist Borys Odiagailo points to such institutional bases of cluster relations as: socialization, collectivism, alienation, mediation, measure of usefulness, measure of value, level of networking, measure of trust (Odyagailo, 2006, p. 344).

Based on the classic features of a cluster according to Michael Porter, we can talk about the cluster as a group of geographically localized interdependent companies, equipment suppliers, components, specialized services, infrastructure, research institutes, higher education institutions (HEls), and other organizations that complement each other and strengthen the competitive advantages of individual companies and the cluster as a whole. That is, a cluster is a group of organizations (companies, enterprises, infrastructure facilities, research institutes, and free economic zones) related to the relationship of territorial proximity and functional dependence in the field of production, sales, and consumption of resources.

The Swedish scientist Ron Boshchma pays special attention to the understanding of "territorial (geographical) proximity" in the study of clusters in his research (Boshchma, 2005). He argues that it is important to distinguish between forms of proximity in the functioning of economic systems. Geographical proximity, in his opinion, is not a specific form. Researcher proved that there are problems of "excessive" proximity, which are expressed in the form of various blockages that can hinder innovation. Ron Boshchma considers geographical proximity as a complementary factor in the formation of institutional, social, organizational, and cognitive proximity (Table 1).

Table 1. Analysis of forms of "intimacy" by Ron Boshchma

\begin{tabular}{|c|c|c|c|c|}
\hline $\begin{array}{l}\text { Forms of } \\
\text { "intimacy" }\end{array}$ & Dimension & $\begin{array}{l}\text { Intimacy } \\
\text { insufficiency }\end{array}$ & $\begin{array}{l}\text { Excess } \\
\text { intimacy }\end{array}$ & Workarounds \\
\hline Institutional & $\begin{array}{l}\text { Institute- } \\
\text { based trust }\end{array}$ & \multirow{3}{*}{ Opportunism } & $\begin{array}{l}\text { Locking and } \\
\text { inertia }\end{array}$ & $\begin{array}{l}\text { Institutional audit and } \\
\text { balancing }\end{array}$ \\
\hline Organizational & Control & & Bureaucracy & $\begin{array}{l}\text { Systems with "weak" } \\
\text { relationships }\end{array}$ \\
\hline Social & $\begin{array}{l}\text { Social- } \\
\text { based trust }\end{array}$ & & $\begin{array}{l}\text { Lack of } \\
\text { economic } \\
\text { justification }\end{array}$ & $\begin{array}{l}\text { Mixing "en-enered" } \\
\text { and market relations }\end{array}$ \\
\hline Cognitive & $\begin{array}{l}\text { "Gap" in } \\
\text { knowledge }\end{array}$ & Misunderstanding & $\begin{array}{l}\text { Lack of } \\
\text { sources of } \\
\text { novelty }\end{array}$ & $\begin{array}{l}\text { Knowledge base } \\
\text { with different but } \\
\text { complimentary } \\
\text { features }\end{array}$ \\
\hline Geographical & Distance & $\begin{array}{l}\text { No spatial external } \\
\text { effects }\end{array}$ & $\begin{array}{l}\text { Lack of } \\
\text { geographical } \\
\text { openness }\end{array}$ & $\begin{array}{l}\text { Change local and } \\
\text { internal links }\end{array}$ \\
\hline
\end{tabular}

Source: Boschma (2005, p. 71). 
Scientists, analyzing the role of institutional factors, consider it as a set of social, organizational and directly institutional forms of "intimacy" (Boshchma, 2005, p. 68). In addition, we believe that the COVID-19 pandemic has provoked new challenges for business and demonstrated the importance of the ability to work in augmented and virtual reality, to digitize business activities. Thus, we interpret virtual reality as a space between reality and virtuality, between which there is augmented reality (closer to reality) and augmented virtuality (closer to virtuality). We believe that virtual reality of the multiplayer world is based on the exchange of virtual goods within the on-line environment. It creates an opportunity to interact with the artificial world with the help of virtual platforms with the available information funds of the on-line innovation market, the ability to work with cloud technologies. Augmented reality as a component of mixed reality is a combination of virtual and real spaces through hardware and software, telecommunications, computer networks, and actually shaping the digital economy.

Within the theme of the article, we consider an innovation-digital cluster as a voluntary informal, institutionalized association of economic entities in terms of not only their territorial proximity, but also their virtualreal "proximity," sectoral similarity and cultural-mental unity in order to obtaining a synergetic effect due to complementarity of processes, resources and interconnectedness of financial, information, knowledge, digital, material flows.

Thus, an innovation-digital cluster is a highly developed virtual-real institutional infrastructure that forms a certain system of dissemination of new knowledge and technologies, accelerates the transformation of inventions into innovations and innovations into competitive advantages, and the development of high-quality stable network connections between all participants. The emergence of such clusters is a natural process in the presence of common digital platforms, scientific and production base. A cluster includes institutions-organizations and institutions that both cooperate and compete with each other. It is a knowledge institution that produces innovations and digital products/services. The main characteristics of innovation-digital clusters are (Zaremskyi, 2010):

- territorial concentration (close location of institutions and organizations creates conditions for rapid economic cooperation, capital exchange);

- the plurality of economic agents (clusters and their activities cover not only the firms in the cluster, but also public organizations, academies, financial intermediaries, institutions that promote cooperation) (Tishchenko, 2010, p. 78-79); 
- formation of a network of informal and formal relations between economic agents (clusters are a complex system, the elements of which are combined by direct and inverse network connections: material, information and financial flows);

- long-term perspective of the cluster life cycle on the basis of the triads "business - university - government" and "venture enterprise - supplier - consumer of digital product/service";

- involvement in the innovation process (venture firms and digital enterprises that are part of the cluster, included in the processes of market/marketing, product, technological, and organizational innovation);

- common institutional, socio-economic, virtual-real environment, characterized by a high level of trust, norms of cooperation, regional traditions and values in communication, innovative culture;

- availability of research work in combination with the dynamic process of digitized learning;

- high quality specialization;

- creation of a special form of innovation - "aggregate innovation and digital products" based on clustering.

Thus, in today's virtual reality, a cluster is a different form of organization of economic relations based on the principles of digitalization. It is characterized by an internal in-depth flow of innovative ideas, digital knowledge and information. During the formation of the network economy in Ukraine, a cluster was used to solve a wide range of tasks, in particular to strengthen the competitiveness of the state, region, industry and the development of regional digital development programs; as a basis for stimulating innovation and digital activities and interaction of large and small businesses; as an important mechanism for the implementation of national industrial policy in the direction of the formation of Industry 4.0 (Dombrovskyi, 2011, p. 241; Kraus, 2018, p. 132).

Conditions for the formation of an innovation-digital cluster from an institutional point of view are presented in Table 2. We agree with the views of Ukrainian researcher Oksana Hryvkivska, who argues that the creation and operation of innovation-digital cluster requires a number of components (Grivkivska, 2011, p. 31):

- innovation, because only new, original, non-standard ideas and knowhow can interest the investor;

- information on the potential of a region, its priorities, investment attractiveness and prospects for development through virtual-real interaction; 
- interest, since only the economic benefit from the invested capital is key to the implementation of real investment projects;

- integration - unification through network interaction of government, business and universities.

Table 2. Conditions for the formation of innovation-digital cluster from an institutional point of view

\begin{tabular}{lll}
\hline Institute level & Institute type & $\begin{array}{l}\text { Characteristics of the environment of } \\
\text { formation of innovative clusters }\end{array}$ \\
\hline $\begin{array}{l}\text { The purpose of } \\
\text { technological level of nation } \\
\text { the Institute }\end{array}$ & \begin{tabular}{l} 
and quality of its resources \\
\cline { 2 - 3 }
\end{tabular} & $\begin{array}{l}\text { State of empathy in society: } \\
\text { the products they create and the } \\
\text { organizations they create can be "best } \\
\text { in the world" }\end{array}$ \\
$\begin{array}{lll}\text { stereotypes and installations of } \\
\text { agents relative to each other }\end{array}$ & $\begin{array}{l}\text { High levels of empathy that stimulate } \\
\text { cooperative behavior }\end{array}$ \\
$\begin{array}{l}\text { Formalized } \\
\text { Institutes }\end{array}$ & $\begin{array}{l}\text { Legislation on the protection of of } \\
\text { property rights }\end{array}$ & $\begin{array}{l}\text { Developed law and enforcement } \\
\text { practice, judicial protection }\end{array}$ \\
\hline $\begin{array}{l}\text { National } \\
\text { informalized } \\
\text { institutes }\end{array}$ & $\begin{array}{l}\text { Distribution of power and } \\
\text { property, level of corruption }\end{array}$ & $\begin{array}{l}\text { Corruption at the permissible level } \\
\text { within the framework of historical } \\
\text { features and evolution of market } \\
\text { relations }\end{array}$ \\
\hline $\begin{array}{l}\text { Local } \\
\text { formalized } \\
\text { institutions }\end{array}$ & $\begin{array}{l}\text { Specially stimulating legislation } \\
\text { and regional state order }\end{array}$ & $\begin{array}{l}\text { Risk of stimulus deformation (may exist } \\
\text { in early stages) }\end{array}$ \\
\hline $\begin{array}{l}\text { Local } \\
\text { informalized } \\
\text { institutions }\end{array}$ & $\begin{array}{l}\text { Level of trust and exchange of } \\
\text { special knowledge }\end{array}$ & $\begin{array}{l}\text { The level of trust is sufficient for the } \\
\text { mutual exchange of special knowledge } \\
\text { that stimulates innovation }\end{array}$ \\
\hline $\begin{array}{l}\text { Local } \\
\text { institutions }\end{array}$ & $\begin{array}{l}\text { The role of local reputation } \\
\text { Source: Gareev (2012, p. 25). }\end{array}$ & $\begin{array}{l}\text { Loss of reputation is equivalent to the } \\
\text { loss of business (or profession) }\end{array}$ \\
\hline
\end{tabular}

The "triple spiral" is more critical for the formation of a mature innovation-digital cluster in the conditions of virtual reality, more precisely - "the collaboration of three types of participants in the innovation game, representing science, business and the state... members of the cluster can use complementary assets and competencies in a variety of combinations, which allows you to expand the benefits created, i.e. increase productivity in its modern sense, typical of the post-industrial economy... Collaboration takes the innovative production culture of the cluster beyond it (through outsourcing, creation of new firms, spillover effects), which leads to the emergence of new network nodes, increasing the competitive strength of the cluster and forming a network environment of virtual reality (Katukov, 2012, p. 26). 
The experience of cluster initiatives in post-industrial countries shows the diversity of mechanisms for the formation and stimulation of innovative cluster formations. Thus, if in the United States the "triple helix" was formed on the basis of a "double helix," namely, "university - business," in European countries with traditional participation of the state. This means a "double spiral" of the "state - business" type. For this reason, in order to implement the vector of modernization of Ukraine's economy on the basis of clustering, there is a need to develop a model of the institutional environment of innovation and digital clusters, which could be applied within the framework of economic practice and current economic downturn in the country, which is also complemented by the challenges of virtual reality. Cluster methodology is based on the consideration of forms of economic relations and directions of creation of "modern innovative and digital products" as a whole set of elements that are in constant interconnection. Accordingly, the foreign scientist Mykhailo Dombrovsky speaks of the cluster as a complex economic system with its own special network connections (Dombrovskyi, 2011, p. 242).

A cluster, as a dynamic system, consists of specific elements, which have the following main characteristics (Togunov, 2009, p. 4):

- form, expressed in the form of specific structure;

- content hidden in the relationship of cluster elements;

- spatio-temporal location, which characterizes the relationship of external and internal institutional environment;

- probable state, which determines the choice of the path of development of a cluster system from all those possible.

The institutional elements and characteristics of a cluster structure are interdependent and interrelated. In our opinion, the highest degree of stability of the internal environment of a cluster is provided by the construction of the cluster, in which the institutional elements that make up and fill it are interdependent.

Such a cluster design is an absolute structure of chiral symmetry (approximate symmetry of strong interaction with respect to transformations and changes). The functional dynamics of the cluster are related to the violation of the symmetry. Such a violation is inherent in the very essence of chirality (a property that consists in difference between right and left), as well as the contradictions of respective pairs of institutional elements that "fill" a cluster structure. The contradiction of two specific institutional elements of a cluster system is resolved through the essence of a third element, which is in a certain pattern of relations with these institutional elements. 
Cluster systems are highly deterministic institutions. The term "determinism" means that a cluster system defines the structure and content, information and energy of this system, the scale of time in it, and therefore its future as a closed or locally closed system is given in specific time and space, despite the possibility of insignificant errors in the real trajectories of the system. That is, the real existence, evolution, and vital activity of a cluster system are impossible without a specific correspondence with the evolution, development, transformation (in the broad sense of the term - movement and change) of the external environment (Togunov, 2009, p. 15) in new conditions of virtual reality of the XXI century.

Currently, the vast majority of Ukrainian clusters, which according to various estimates reach 50 , are in the process of formation. The most popular for their creation are the tourism industry, food and engineering industries, while science-intensive - electronics, alternative energy, nanotechnology and pharmaceuticals - are represented (Figures 1 and 2). The leader of clustering in the field of high technologies and existing organizations that perform scientific and technical work is the Kharkiv region and the city of Kyiv (Table 3) (Bila, 2011, p. 25).

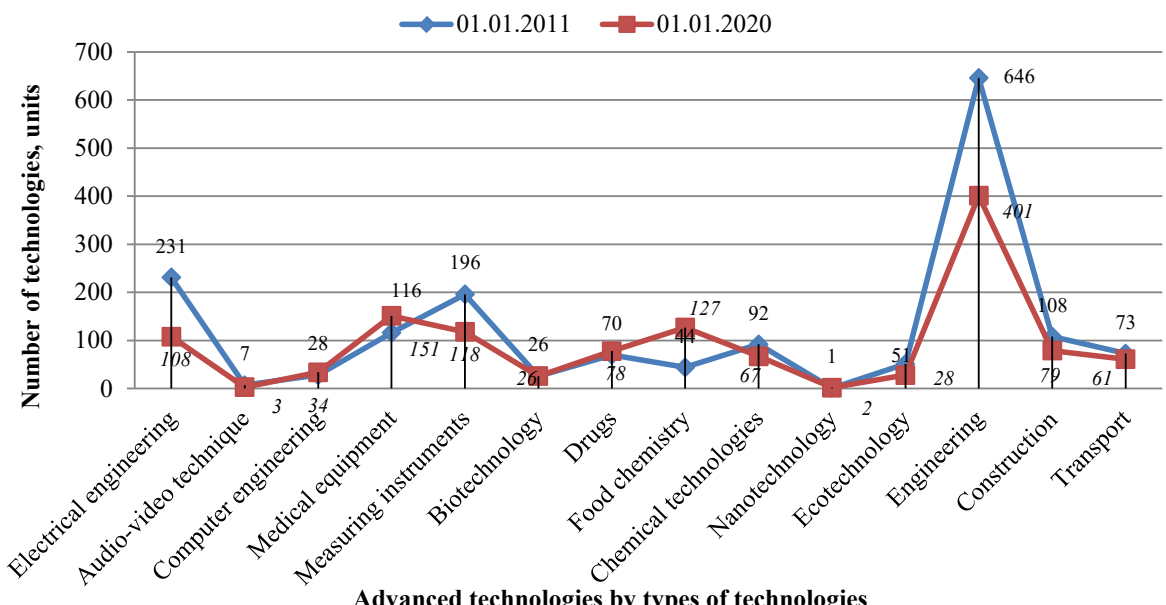

Advanced technologies by types of technologies

Figure 1. The number of advanced technologies created by Ukrainian clusters in the main technical areas in different sectors of the economy Source: Built by authors based on source 69 .

The pioneer of clustering in Ukraine is the Khmelnytsk region, where construction and sewing clusters have been operating for over 10 years, and in 2002 the first tourist cluster in Ukraine "Oberig" was launched, designed 
as a public organization. It included more than 50 representatives of agriculture, farmers, fishermen and craftsmen. In the Zaporozhia region the machine-building cluster of LLC "AgroBUM" successfully operates. It unites 20 companies and develops cooperation on the principles of subcontracting. In the Ivano-Frankivsk region there is a well-known Tysmenytsia fur cluster on the basis of OJSC "Tysmenytsia Fur Company." In the Rivne region, there is a woodworking cluster named "Polissya Rokytnivshchyna," which was created in 2003 (Bila, 2011, p. 26).

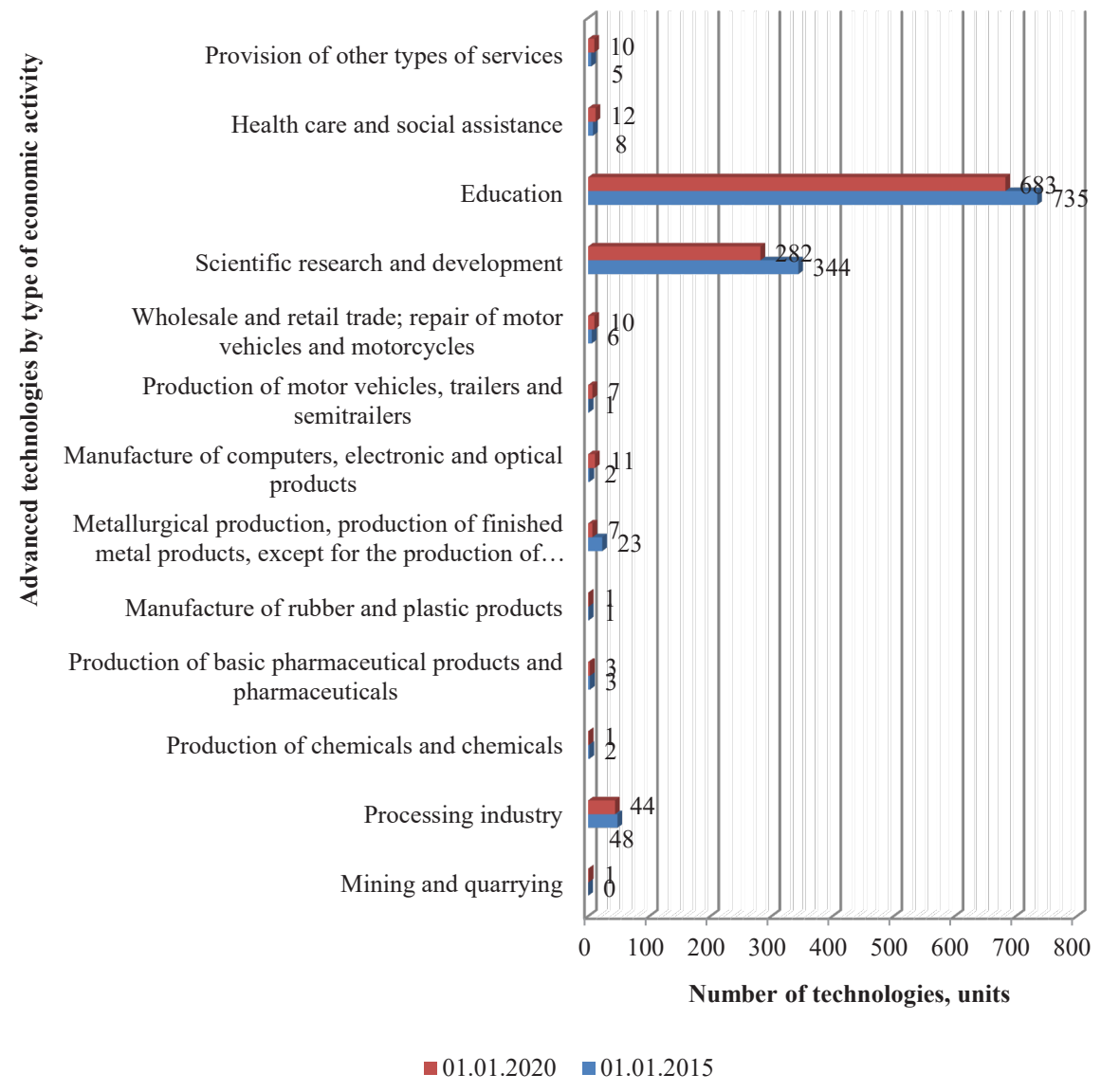

Figure 2. The number of advanced technologies created by Ukrainian clusters by type of economic activity

Source: Built by authors based on source 69 .

A promising direction for Ukraine is the creation of cross-border clusters. Given that 19 of the 25 oblasts are border regions, Ukraine has every opportunity to cooperate with foreign companies within cross-border 
clusters. An example of such cooperation is the Ukrainian-Romanian "First Agrarian Cluster," established in 2009 in the Chernivtsi region. Within the framework of the Cross-Border Cooperation Program Poland-BelarusUkraine for 2007-2013, a Ukrainian-Polish tourist and recreational cluster was formed (Bila, 2011, p. 27).

Table 3. The share of the number of innovation-active enterprises involved in innovation cooperation, by type of partners by region

(\% to the total number of innovation-active enterprises of the respective region)

\begin{tabular}{|c|c|c|c|c|c|c|c|c|c|c|c|c|}
\hline & \multicolumn{2}{|l|}{ Total } & \multicolumn{10}{|c|}{ Including } \\
\hline & \multirow[b]{2}{*}{ 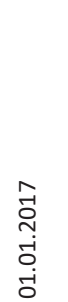 } & \multirow[b]{2}{*}{$\begin{array}{l}\text { శ్ } \\
\text { ஸे } \\
\text { - } \\
\text { - } \\
0\end{array}$} & \multicolumn{2}{|c|}{ 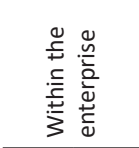 } & \multicolumn{2}{|c|}{ 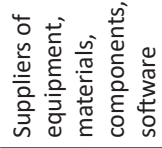 } & \multicolumn{2}{|r|}{$\begin{array}{l}\frac{n}{\mathscr{U}} \\
\frac{\stackrel{U}{U}}{U}\end{array}$} & \multicolumn{2}{|c|}{ 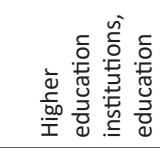 } & \multicolumn{2}{|c|}{ 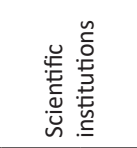 } \\
\hline & & & 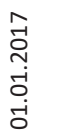 & 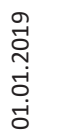 & 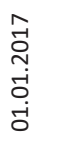 & 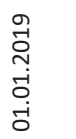 & 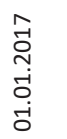 & 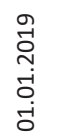 & 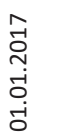 & 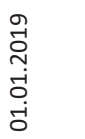 & 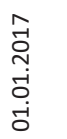 & 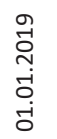 \\
\hline Ukraine & 34.4 & 58.3 & 14.3 & 31.1 & 26.1 & 52.0 & 13.7 & 16.4 & 5.9 & 5.8 & 8.4 & 9.6 \\
\hline Vinnytsia region & 51.9 & 75.8 & 29.1 & 56.1 & 25.3 & 54.5 & 11.4 & 9.1 & 5.1 & 4.5 & 5.1 & 21.2 \\
\hline Volyn region & 33.3 & 80.4 & 9.5 & 10.7 & 30.2 & 78.6 & 3.2 & 5.4 & - & 1.8 & 1.6 & 1.8 \\
\hline Dnipropetrovsk region & 28.5 & 58.1 & 12.2 & 25.9 & 19.9 & 54.1 & 11.9 & 25.2 & 6.5 & 5.2 & 9.2 & 10.4 \\
\hline Donetsk region & 46.9 & 76.1 & 18.4 & 64.2 & 32.7 & 59.7 & 20.4 & 23.9 & 12.2 & 13.4 & 18.4 & 26.9 \\
\hline Zhytomyr region & 24.7 & 62.5 & 4.5 & 31.3 & 20.2 & 60.0 & 10.1 & 11.3 & 5.6 & 3.8 & 9.0 & 10.0 \\
\hline Zakarpattia region & 46.5 & 75.4 & 23.3 & 21.1 & 37.2 & 70.2 & 25.6 & 8.8 & - & - & 2.3 & 1.8 \\
\hline Zaporizhia region & 25.4 & 28.8 & 10.9 & 17.6 & 18.1 & 23.2 & 10.1 & 15.2 & 7.2 & 10.4 & 10.9 & 12.0 \\
\hline Ivano-Frankivsk region & 28.8 & 25.0 & 11.0 & 8.3 & 19.2 & 22.2 & 12.3 & 6.9 & 1.4 & - & 8.2 & 2.8 \\
\hline Kyiv region & 47.0 & 63.0 & 19.7 & 37.0 & 42.4 & 59.1 & 26.5 & 15.6 & 12.1 & 6.5 & 12.9 & 11.0 \\
\hline Kirovohrad region & 22.9 & 86.2 & 12.9 & 60.9 & 18.6 & 81.6 & 5.7 & 13.8 & 1.4 & 2.3 & 2.9 & 5.7 \\
\hline Lugansk region & 53.8 & 92.3 & 26.9 & 34.6 & 46.2 & 76.9 & 15.4 & 15.4 & 11.5 & - & 19.2 & 15.4 \\
\hline Lviv region & 30.4 & 56.1 & 10.6 & 43.9 & 27.5 & 53.5 & 13.5 & 13.9 & 7.2 & 5.3 & 7.7 & 7.5 \\
\hline Mykolaiv region & 26.8 & 71.9 & 12.7 & 43.9 & 18.3 & 71.9 & 9.9 & 14.0 & 5.6 & 5.3 & 8.5 & 8.8 \\
\hline Odessa region & 32.5 & 66.1 & 18.8 & 38.3 & 24.4 & 60.0 & 13.1 & 8.7 & 6.3 & 10.4 & 10.0 & 12.2 \\
\hline Poltava region & 20.9 & 53.2 & 1.8 & 12.8 & 16.4 & 39.4 & 6.4 & 20.2 & 4.5 & 6.4 & 6.4 & 8.5 \\
\hline Rivne region & 47.3 & 72.2 & 20.0 & 44.4 & 43.6 & 44.4 & 14.5 & 33.3 & 0.9 & - & 1.8 & 5.6 \\
\hline Sumy region & 33.3 & 58.9 & 13.0 & 46.6 & 27.5 & 38.4 & 20.3 & 23.3 & 7.2 & 6.8 & 10.1 & 19.2 \\
\hline Ternopil region & 30.9 & 66.7 & 13.2 & 28.7 & 25.0 & 56.3 & 14.7 & 14.9 & 2.9 & 1.1 & 2.9 & 1.1 \\
\hline Kharkiv region & 31.7 & 55.8 & 12.3 & 16.2 & 24.6 & 49.7 & 16.0 & 14.1 & 6.0 & 5.5 & 7.3 & 5.5 \\
\hline Kherson region & 38.0 & 50.0 & 12.0 & 35.0 & 32.0 & 47.5 & 14.0 & 7.5 & - & 7.5 & 10.0 & 12.5 \\
\hline Khmelnitskyi region & 29.5 & 60.7 & 4.5 & 25.0 & 27.3 & 41.1 & 11.4 & 3.6 & 4.5 & - & 4.5 & - \\
\hline Cherkasy region & 17.6 & 18.6 & 7.4 & 12.9 & 11.8 & 15.7 & 2.9 & 1.4 & 1.5 & 1.4 & 2.9 & 4.3 \\
\hline Chernivtsi region & 42.9 & 26.7 & 14.3 & 13.3 & 33.3 & 20.0 & 14.3 & 13.3 & - & - & 14.3 & 13.3 \\
\hline Chernihiv region & 34.0 & 54.1 & 18.0 & 32.4 & 20.0 & 51.4 & 10.0 & 13.5 & 4.0 & 8.1 & 6.0 & 5.4 \\
\hline
\end{tabular}

Source: Kuznetsov (2019, p. 105). 
Most of the hubs and coworking centers operating in Ukraine are private. Today there are about 200 coworking spaces in Ukraine, some of which have become meeting places for startups. A successful example is the Kyiv coworking center "Magazine", where business trainings, master classes, educational lectures, conferences, and competitions in the field of innovation are held. In 2012, the Cabinet of Ministers approved a resolution on the national project "Technopolis," which provides for the construction of innovation parks in Kyiv, Kharkiv, Lviv, and Dnipro and the creation of 7075 thousand jobs for specialists in IT, biotechnology, energy conservation, nanotechnology. The Ukrainian Silicon Valley was supposed to be the Bionic Hill Innovation Park, near Kyiv. However, the project failed due to a lack of adequate government and financial support (Tarasova, 2007).

Today, the activity of the Association "Innovative Development of Ukraine" can be considered successful, as it promotes the implementation of promising Ukrainian innovation projects and is working on bills on industrial parks and providing benefits to their members. In 2015, the opening of the California in Ukraine innovation center in Kyiv was announced. In the premises provided for use by the Kyiv administration, master classes on the implementation of innovative projects, hackathons are held. A network of innovations and entrepreneurship support centers called iHUB is operating effectively in Ukraine. iHUB was initiated by the global network of national non-profit foundations Seed Forum in 2014. iHUB operates with the support of the Norwegian Ministry of Foreign Affairs and the Embassy of the Kingdom of Norway in Kyiv, with additional funding from the development institutes of Finland, Sweden and England. From the grant funds, iHUB pays the rent and work of research staff in Kyiv, Chernihiv, Lviv, Vinnytsia, Ivano-Frankivsk, where a number of structural centers operate within the framework of the public-private partnership iHUB. Already today, more than 50 experts from 20 countries work in structural centers in 40 areas of educational and innovative events. iHUB invests in reconstruction, equipment and project management, and assumes all operational and financial risks during the partnership term. According to experts, about 20 thousand people showed interest in this project and became its participants in order to gain knowledge to create startups (Vlasenko, 2015).

We believe that in order for innovation hubs to develop, government agencies should provide orders and innovation projects to hub participants on a competitive basis. Examples are the automation of urban processes and the introduction of electronic administrative services, both relevant in the light of government-initiated reforms. In addition, from 2016, the Seed Forum plans to launch e-government and E-parliament Electronic Services projects on the basis of iHUB. It is assumed that part of the resources of the 
innovation center will be used for the development of electronic services of government agencies, funded by a grant from the Norwegian government.

The international innovation cluster "Competitiveness" functions effectively in Ukraine. It is a voluntary association of Ukrainian, foreign educational and scientific institutions and industrial formations of various forms of ownership on the principles of common interests in order to promote the effective scientific, educational, organizational, and entrepreneurial activities of its founders and participants.

The creation of this cluster is due, firstly, to the need to ensure the innovative breakthrough of individual industries; secondly, traditional science and education are unable to respond in a timely manner to existing acute problems - society is developing faster than knowledge; thirdly, the need for an innovative economy based on the active use of the results of science and best practices and knowledge, which are formed on the basis of continuing education.

The main activity of the cluster "Competitiveness" is to create the foundations for effective research and educational activities, so as to ensure the alternative development of priority industries and the implementation of projects such as "Formation of a business incubator and recruitment agency for targeted use of youth potential," "Improving educational level", and "Retraining and advanced training of specialists in market specialties (for market needs)" (International Innovation Cluster "Competitiveness," 2011).

Scientific and educational institutions and industrial formations are involved in the cluster, which actively use innovations in their activities and intend to continue such activities to intensify the process of combining science with production. The participants of the international innovation cluster are:

- Institute of Economics, Technology and Entrepreneurship;

- Ternopil Institute of Agricultural Production of NAASU;

- Khmelnytsk University of Economics;

- Podolsk State Agrarian Technical University;

- University of Economics and Entrepreneurship;

- Ternopil Institute of Social and Information Technologies;

- Bukovynna State Financial Academy;

- King Danylo Halytsky University of Law;

- Panstwowa Wyzsza Szkola Techniczno-Ekonomiczna im. ks. Markiewcza in Yaroslavl;

- Agricultural Advisory Service "Agronauka;"

- Small enterprises in the field of innovations.

Among the products created by the cluster "Competitiveness" are: remote production (research schools, training and retraining of scientific 
and professional staff, conducting research and testing in their own research and production journals "Innovative Economy" and "Sustainable Economic Development" and information-consulting newspaper "Consultant", conducting scientific and practical Internet conferences, seminars, round tables to improve the educational and professional level of the population using competitions of scholars in various fields) and organization in the cluster system of an innovation bank, implementation of innovation transfer and diffusion innovative business projects.

The scientific school of the cluster is working on the development of international competitive projects under the cross-border cooperation program: "Poland-Belarus-Ukraine" and "Romania-Ukraine-Moldova." The defined conditions of the cross-border cooperation program "PolandBelarus-Ukraine" stipulate that the minimum amount of the tender project is $€ 100$ thousand, the maximum $-€ 3$ million.

Already today, the international innovation cluster "Competitiveness" initiates the implementation of educational, scientific and technological innovation and investment projects in the regions of Ukraine. The implementation of these projects is based on the cooperation of scientific, educational, industrial institutions and local governments in the following areas:

- formation of competence and employment of the population (innovative-educational project, the activity of which is based on the business personnel incubator "Universal" and the personnel recruitment agency);

- improving the management and technological structure of production to intensify innovative business activities;

- creation of an innovative technopark "Agroecological", the purpose of which is: reproduction and rational use on an ecological basis of the productive potential of rural areas as the main means of solving the food and energy problem of the country and increase its global competitiveness (International Innovation Cluster "Competitiveness", 2011).

Based on the above theoretical and methodological analysis and our own observations, Figure 3 visualizes a slice of network interaction of cluster formations in the conditions of virtual reality. "The innovative and digital nature of modern clusters is determined not by the actualization of their specialization, but by their unique institutional design. Based on a spiral model, they form a striking contrast (difference) with structural formations of other types of territorial-industrial agglomerations" (Katukov, 2012, p. 27). 


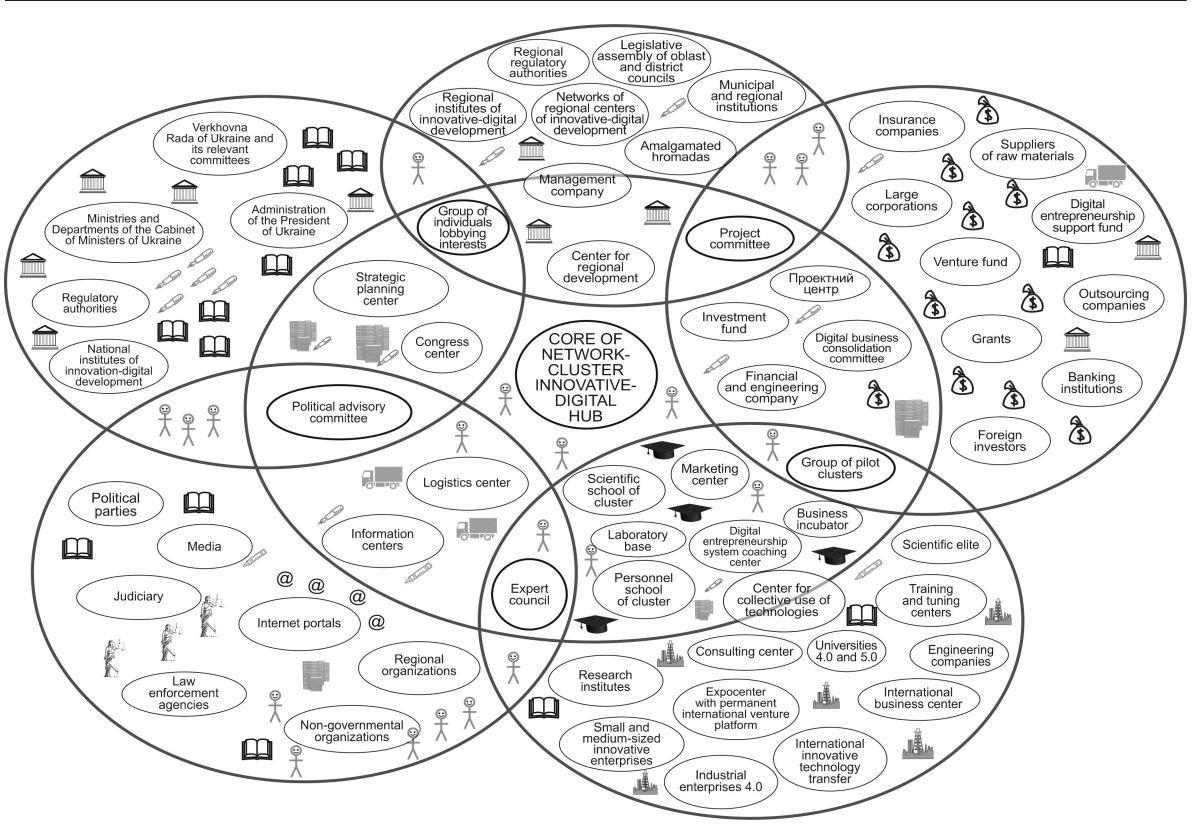

Figure 3. Visualization of network interaction of cluster formations in the conditions of virtual reality

Source: Compiled by authors on the basis of sources Togunov (2009); Napolskikh (2012, p. 42); Kraus (2014); Kraus (2019); Britchenko (2019, p. 452) and own developments.

It should be noted that in addition to solving their specific problems, each subject of the institutional environment of the innovation-digital cluster (Figure 3) performs universal functions that are inherent in all institutions of cluster formations. Among these functions are: regulatory; integrative; broadcasting; communicative (this feature has its own feature - informal communication); consolidation and reproduction of social relations (Napolskikh, 2012, p. 43).

Superimposed on other circles and forming a so-called "spiral," the center circle in Figure 3 illustrates the effects of synergy on the joint interactive network interactions. These actions are aimed at achieving in the innovationdigital cluster "the effect of digital development and innovative growth, which are based on the dynamism of constant renewal and continuous growth of digital production" (Katukov, 2012, p. 26). At the intersection of the inner circle of the innovation-digital cluster (which demonstrates its internal environment) with five other circles (circles that conditionally demonstrate the external institutional environment), there are informal and formal institutions-institutions of cluster (Napolskikh, 2012, p. 42) with their virtually real relationships. 
The interaction of the principles of the "triple spiral" is built at the level of each new cluster, and it then spreads like a matrix, on the scale of the economy as a whole. "There is network repeatability: each cluster generates similar structures, with a similar synergistic effect of innovation, which makes economic growth innovation oriented" (Katukov, 2012, p. 27).

We agree with Dmytro Napolskykh that "the institutional environment of innovation and digital clusters, including the system of social institutions, organizations and their relationships, is a key part of the institutional environment of the territory that is developing most dynamically" (Napolskikh, 2012, p. 42). The scholar emphasizes that the institutional environment of territories necessarily consists of formal and informal institutions. He refers to the formal as only hierarchically built regulatory frameworks, public authorities and local governments, budget, commercial and public organizations. Dmytro Napolskykh defines informal institutions as "forms of social interactions that have developed on the territory as a result of a long process of social evolution" (Napolskikh, 2012, p. 42). Among such forms, he names religious, moral and ethical, economic.

It is worth noting that fully fledged clusters, which are designed for innovation-digital types of growth, received an impetus for development only in the post-industrial era. Their competitive advantages are associated not only and not so much with territorial proximity of participants, but with their functional interdependence and complementarity (Katukov, 2012, p. 28).

- Cluster systems are characterized by the following features (Dombrovskyi, 2011, p. 242):

- the existence of a corporate management system, control over a business process, collective economic monitoring;

- the presence of a leading enterprise that determines long-term economic, innovative and digital strategy of a regional economic system;

- territorial localization of the bulk of business entities-members of a cluster system;

- stability of strategic economic ties within a cluster system, including its regional, interregional, domestic and international relations;

- creation by members of a cluster of a non-profit association, voluntary membership, the presence of a coordinating organization;

- long-term coordination of interaction of participants of a cluster system within its national and intraregional programs of digital development, investment projects, network processes Cluster systems can bring together large, small and medium-sized enterprises. Basis on the success of such associations is the synergetic effect of geographical proximity to each other and to consumers. They can be formed by 
industry profile, i.e. sectoral. Economic agents of cluster systems have every chance to become (Orev, 2011, p. 320):

- research institutes and educational organizations;

- organization of innovation infrastructure and infrastructure to support small and medium enterprises (business incubators, special economic zones, technology parks, venture funds, knowledge transfer centers);

- firms specializing in specialized, usually competitive, digital activities;

- firms-suppliers of raw materials, goods or services for profile enterprises;

- non-profit and public organizations, associations of entrepreneurs, chambers of commerce and industry;

- enterprises that provide access to information, engineering, transport, energy and other infrastructures.

A synergetic approach used in the formation and development of innovation-digital clusters is considered through the prism of the relationship "subject - the subjective relationship of innovation-active organizations and digital enterprises" (Andriichuk, 2010, p. 44). In addition, in our case, this effect lies in the plane of restructuring "old" development institutions in "new" under the influence of the relevant institutional and legal basis, systemic and comprehensive modernization and diversification of all sectors of production, improvement of the innovation and investment situation, construction of an effective innovation and digital virtual-real infrastructure of the European standard, implementation of clustering of the economy using the opportunities of network cooperation.

It is the theory of finite sets, studying the rules: how, knowing the number of elements of some sets, gives the answer - how to calculate the number of elements of other sets that are composed of the first sets with some operations. The basic space of a self-organized socio-economic system on the way to building an innovation system can be qualified as a kind of network set. This network set is based on:

- formation by institutes-organizations of the innovative development of network structures based on relations of trust and systems of interaction, first of all, horizontal;

- complicating the functioning of a modern socio-economic system in the context of globalization and the formation of a digital economy.

Returning to the analysis of Figure 1, it should be noted that we made an attempt to conditionally represent network economic space, which implies the presence of many "new" institutions of innovation and digital development, which determine new rules for the formation of network 
interaction. From the standpoint of set theory, the peculiarity of innovationnetwork structures is that they allow you to create a variety of mechanisms of interaction. Under these mechanisms, institutions-organizations of innovation and digital development, which are part of the network structure, retain the status of legal entities. It should be noted that in innovationnetwork structures, there is not just cooperation of different institutionsinstitutions and institutions-organizations, but their coherent interaction when they function as a whole, increasing their economic and institutional capabilities and forming a synergetic effect or synergism. Synergism is the result of a complex interaction of measures that provide additional efficiency of digital enterprise more than the simple arithmetic sum of the effects of individual measures/methods. This concept is also called the synergetic effect " $2+2=5$ " (Redina, 2009, p. 155).

As a result of such an interaction, a "new" institutional structure in the innovation sphere is constantly emerging, which provides for the presence of digital enterprises that carry out their risky activities both within existing development institutions and within the framework of "new" institutes of innovation and digital development created by them in the conditions of virtual reality. These institutes will make the internal organization of an innovation and network structure (cluster structure, technical and technological zone, technopolis, technopark, innotech).

During digital economic development, in the conditions of institutional uncertainty, the enterprises of the sphere of innovation can make collective decisions concerning new rules of network interaction and produce their own institutions. These institutions are "born" and founded to:

- structuring of new directions of collective interactions;

- creating opportunities to find new rules and norms of these interactions;

- developing effective compromise solutions, the adoption of which leads to the benefit of all participants in the innovation-digital process.

Based on this, we can safely say that having made its choice in favor of a European vector of development, the national economy of Ukraine has become transitional, as it joins the conditions of forming contours of a global network-digital economic system. That is, it is characterized by transitional institutional states. This opinion is shared by Ukrainian scientist Dmytro Lukianenko (Lukianenko, 2008).

The high degree of interaction between universities and business and the state, shown in Figure 1, is based on new organizational principles network structures that unite once isolated innovation centers in universities, 
industrial firms, and government agencies. These networks can consolidate the intellectual, material and financial resources of several universities, public research centers, and innovation structures of private firms located in the same region or in different regions of the country. Moreover, on a virtual-real basis, they can unite research, educational and commercial organizations in different countries (Ivanov, 2013, p. 18). Qualitatively, a new nature of organizational forms of interaction of innovation-digital structures creates an incubation effect - universities and research organizations of the state and business are transformed into incubators of new innovation firms, digital enterprises and research organizations. Prerequisites for this are (Ivanov, 2013, p. 18):

- selection of the most promising ideas in the field of technology;

- sufficient funding in the form of grants and interest-free loans;

- outsourcing;

- training of staff of future companies during practical work;

- inclusion of firms with professionally trained staff in a common network with potential partners and investors.

The basis of the architecture of the network economy is formed by innovation-digital organizations and industry clusters - groups of closely related enterprises on the production principle, localized territorially, and jointly promoting innovative products and digital services to the innovation market. Factors such as mutual trust, partnership, use of a common information field, joint scientific and technical centers, marketing structures and sources of funding, support of local chambers of commerce and regional administration are of key importance. Ensuring such a high level of cooperation is impossible without clear legal norms governing the behavior of all subjects of the joint innovation and digital network and their relations with external business structures and authorities (Ratner, 2011, p. 20).

The activity of innovation-digital structures operating in the conditions of virtual reality is based on four principles (Androschuk, 2010, p. 323-324):

- maximum convergence of science, production, commerce;

- creation of the most favorable conditions for the development of science-intensive production, innovative business, digital entrepreneurship;

- associations of firms that develop and provide commercial sales of various types of science-intensive products and promote accelerated processes of exchange of scientific and technical information;

- formation of scientific conditions for the incubation period of formation of small innovative firms, carrying out the first, most scientific stage of scientific and technical developments. 
Global experience has already shown that the conditions for successful partnership in the internal environment of the cluster in virtual reality based on network interaction are openness, transparency and the high professionalism of partners. With reference to the professionalism of partners, it should be noted that in the implementation of socio-economic programs and investment projects, their performers are dealing with living people, nature or the law. Unprofessionalism and low ethical standards can harm target groups to which the beneficial effects of programs or projects are directed. The issue of implementing ethical norms and professional standards within the partnership should be taken into account by all partners. Effective partnership is impossible without a special intellectual and cultural environment (in innovative business and digital entrepreneurship it is called corporate culture), that is, a collective system of business principles, norms of behavior, traditions, symbols, rituals and beliefs, which would be understood by most economic agents (Khomenko, 2007, p. 167-168).

- Cluster systems based on network cooperation are formed on the basis of three principles, depending on the structure, size, and type of activity (Dombrovskyi, 2011, p. 242):

- concentration - location convenient for regular contacts;

- common interests of potential participants - the same, or interdependent areas of activity, common market or area of activity;

- interaction - relationships, interdependence with a large variety of formal and informal relationships.

- As a result, it should be noted that at a mesoeconomic level we already see how financial-industrial groups of enterprises, research and production networks, cluster structures, interregional complexes, technology parks, megacities, free economic zones, business incubators, and venture enterprises interact. If we consider the transformation of the economic complex of the region to combine all intermediate formations within one middle level and leave the regional economic complex on the basis of innovationdigital cluster formation as an independent, we obtain the following sequence: megaeconomics - macroeconomics - mesoeconomics - microeconomics - minieconomics - nanoeconomics (Kolodinskyi, 2008, p. 19). The meso-level, in contrast to others, is less stable and is under the influence of adaptive transformation and strategic changes within the regional innovation market.

One of the main elements of the infrastructure that determines the development of a portfolio of innovation and digital strategic alternatives of the economic cluster at the meso level is the institutional component. This is due to the fact that market infrastructure acts as an institutionalized 
transaction (agreement that is accompanied by mutual actions and deeds) (Tolstykh, 2009, p. 85).

\section{CONCLUSION}

Summing up our study, it should be noted that the network economy in the XXI century, like no other economy (innovative, informational, knowledgeable, blue, green, circular, row, digital), highlights the organic relationship of technological (virtual-real networks) and institutional specifics of a constantly updated way of life (a networked social environment).

It is the network economy that demonstrates new forms of qualitative accumulation and augmentation of new knowledge that occur through their network replication (division), and innovative growth is the result of the formation in the economy and society of a new, network model of coordination, networking of new quality, which is constantly adjusted by digital tools. As authors of the article, we can also state that it is obvious that the transition to a network economy is not enough to create the latest production infrastructure (digital platforms, business incubators, innovation hubs, industrial parks, technology platforms, coworking centers, technology parks, venture funds, etc.). Why? Because in the absence of the necessary density of social cooperation, in the case of a shortage of democratic institutions and a low level of public confidence, such an infrastructure will work idle.

The managerial consequences of our research are the formation of a new quality of cluster solutions, designed to create appropriate conditions and ensure the essential changes needed for innovative-digital development institutions, to direct the potential of all stakeholders in the development of national and international innovation clusters in the conditions of virtual reality, to create potential for economic development of the whole country. An example of such an initiative is the cluster service, the main purpose of which is to create conditions that will ensure the self-organized formation of clusters by the mechanism "top-down" in the future, and the role will be revealed through the organic unification of separate interests of government, science and business representatives on a fair, equal, parity basis due to the presence of their own interest, which does not contradict, but complements the interests of all stakeholders, forming synergy effects. The prototype of the cluster service at the current stage can be considered a project of educational and scientific diplomacy initiated by the National Center "Small Academy of Sciences of Ukraine".

The synergistic effect of networking creates a new phenomenon of growing marginal utility and growing marginal productivity from innovative 
glocalization and digital globalization. The greater the scale of innovation and digital activities is in the conditions of virtual reality, the greater the efficiency is of the use of additional resources. The effect of scale is especially pronounced within the network, which uses the standards produced and tested by it. Network structure helps to increase the digital competence of the members of all, without exception, economic agents of clusters. Standards in the network economy are becoming a major factor in competitiveness at all levels of aggregation.

Thus, the formation of a new quality of networking and cooperation is a new approach to solving the problem of competition in virtual reality and in the digital market for goods/services. This trend is a consequence of rapid digital development and the spread of high-tech products and integrated solutions in the modern economy, the processes of accelerated improvement of digital technologies, and high levels of risk in new markets.

Despite the scale of existing scientific achievements, it is still important in the future to conduct research aimed at understanding the ideology of the digital economy, in order to form a new virtual reality. There is a need to develop high-quality institutions that would accelerate digital development in terms of augmented reality, as well as to focus on the work of tools in terms of effective legislative and institutional capacity for digitalization of national economies. Research is needed to find answers to the following questions: How is virtual reality different from digital, augmented, augmented, augmented, augmented, and mixed realities? How is it possible to work in a digital ecosystem with an innovation ecosystem? How can digital entrepreneurship, start-up, and the state "in the smartphone", influence the development of innovations and derive economic benefits from it?

\section{Acknowledgments}

The research was conducted within the project "Teaching Digital Entrepreneurship" (TED) of the EU Erasmus + KA2 - Cooperation for innovation and the exchange of good practices KA203 - Strategic Partnerships for higher education, Form ID: KA203-E3839A4A, No. ERASMUS-PL-KA203-1/2020. This article reflects the views only of the authors, and the Commission cannot be held responsible for any use which may be made of the information contained therein.

\section{References}

Andriichuk, V. H. (2010). Innovative modernization of the domestic economy: Strategic guidelines and mechanism of their implementation. Foreign Trade: Economy, Finance, Law, 1, 4-8. 
Androschuk, H. O., Zhiliaev, I. B., Chizhevskyi, B. H., \& Shevchenko, M. M. (2009). Strategy of Innovative Development of Ukraine for 2010-2020 in the Conditions of Globalization Challenges. Kyiv: Parliamentary edition.

Bila, S. O. (2011). Innovative approaches to regional development in Ukraine: analytical report. Kyiv: NISD. Retrieved from https://niss.gov.ua/sites/ default/files/2012-03/innovation_Bila.indd-bb655.pdf

Boschma, R. (2005). Proximity and innovation: A critical assessment. Regional Studies, 39(1), 61-74. https://doi.org/10.1080/0034340052000320887

Boudeville, J.-R. (1966). Problems of Regional Economic Planning. Edinburgh: Edinburgh University Press.

Britchenko, I., Kraus, N., \& Kraus, K. (2019). University innovative hubs as points of growth of industrial parks of Ukraine. Financial and Credit Activities: Problems of Theory and Practice, 4(31), 448-456. https://doi. org/10.18371/fcaptp.v4i31.190996

Cappellin, R. (2003). Territorial knowledge management: Towards a metrics of the cognitive dimension of agglomeration economies. International Journal of Technology Management, 26, (2-4), 303-325.

Cappellin, R. (2007). The territorial dimension of the knowledge economy: Collective learning, spatial changes, and regional and urban policies. American Behavioral Scientist, 50(7), 897-921. https://doi. org/10.1177/0002764206298316

Chesbro, G. (2007). Open Innovations. Moscow: Generation.

Cooke, P. (2006). Proximities, knowledges and innovation biographies. Studia Regionalne i Lokalne, 2(24), 21-47.

Cooke, P., \& Martin, R. (2006). Clusters \& Regional Development. Hampshire: Routledge.

Deliia, V. P. (2011). Innovative Economy and Sustainable Development. Balashikha: De-Po.

Dlugopolskyi, O. (2003). Cluster model of industrial production development as a factor of effective structural reforms (on the example of Ternopil region). Economic Journal, XXI. Retrieved from http://soskin.info/ ea/2003/2/20030225.html

Dombrovskyi, M. A. (2011). Methodological problems of economic clustering. Problems of Modern Economy, 2, 241-245.

Enright, M. J. (1992). Why clusters are the way to win the game? Word Link, 5, 24-25.

Erokhina, E. A. (2011). Concepts of self-organization as a new methodology for the study of economic systems. Innovations, 4(150), 79-84.

Evans, P. (2006). Government action, social capital and development: reviewing the evidence on synergy. World Development, 24(6), 11191132.

Fedorenko, V. G., Tugay, A. M., Goyko, A. F., \& Dzhabeylo, V. B. (2008). The concept of cluster policy in Ukraine. Economy and State, 11, 5-15. 
Fedorov, V. K., Epaneshnikova, I. K., \& Ganza, A. N. (2010). On the unconditional principles and contradictions of development of open innovations. Innovations, 7(141), 116-119.

Gareev, T. R. (2012). Clusters in institutional projection: to the theory and methodology of local socio-economic development. Baltic Region, 3, 7-33.

Grivkivska, O. V., \& Kurguzenkova, L. A. (2011). Clusters as a model of innovative development of enterprises. Scientific and Technical Information, 3, 30-32.

Haken, G. (2005). Information and Self-Organization: A Macroscopic Approach to Complex Systems. Moscow: KomKniga.

Holian, V. A. (2006). Problems of formation of the institutional environment of national economy in the conditions of market relations. Current Economic Problems, 5, 4-11.

Innovation Clusters: Drivers of National Innovation System. (2003). Paris: OESD.

International Innovation Cluster "Competitiveness". (2011). Retrieved from http://www.stelmaschuk.info/about-the-cluster/claster.html

Ivanov, N. (2013). The social context of innovative development. World Economy And International Relations, 5, 17-30.

Karetin, S. S. (2009). Formation of cluster policy and management aspects of its implementation. Problems of Modern Economics, 1, 320-322.

Katukov, D. D., Malygin, V. E., \& Smorodinskaya, N. V. (2012). Institutional Environment of Globalized Economy: Development of Network Interactions. Moscow: Institute of Economics RAS.

Khomenko, Ya. V. (2007). Institutional environment as the basis of sustainable economic growth. Scientific Works of DonNTU. The Series is Economic, 31(3), 164-168.

Kolodinskyi, S. B. (2008). Innovation clusters in the development of the regional economy. Science newsletter of Poltava University with the cooperative cooperation of Ukraine. Series: Economics of Science, 4, 18-24.

Kraus, N. M. (2014). Institutional aspects of clustering in the innovative economy under the influence of systemic and complex modernization. Economic Journal, XXI(5-6), 29-32.

Kraus, N. M. (2019). Innovative Economy In The Globalized World: Institutional Basis Of Formation and Trajectory of Development. Kyiv: Agrar Media Group.

Kraus, N. M., \& Kraus, K. M. (2018). What changes does Industry 4.0 bring to the economy and production? Formation of Market Relations in Ukraine, 9(208), 128-136.

Kropyvko, M. F. (2010). Conceptual approach to cluster organization and management of agro-industrial production. Economics of Agro-Industrial Complex, 11, 3-13.

Kryvoruchko, O. S., Kraus, N. M., \& Kraus, K. M. (2018). Virtual reality of the national information and innovation space. Economy and Society, 14, 22-35. Retrieved from http://economy and society.in.ua 
Kuznetsov, M. S. (2019). Scientific and Innovative Activity of Ukraine: Statistical Collection. Kyiv: State Statistics Service of Ukraine. Retrieved from http://www.ukrstat.gov.ua/druk/publicat/kat_u/2019/zb/09/zb_ nauka_2018.pdf

Kuznetsova, O. V. (2002). Economic Development of Regions: Theoretical and Practical Aspects of State Regulation. Moscow: Editorial URSS.

Lagendijk, A., \& Oinas, P. (2005). Proximity, Distance and Diversity. Issues on

Economic Interaction and Local Development. New York: Routledge.

Lukianenko, D. (2008). Global Economic Integration. Kyiv: National Textbook LLC.

Mazniev, G. le. (2015). Methodological principles of creation and effective functioning of innovative technological clusters. Economics of AgroIndustrial Complex, 1, 70.

Napolskikh, D. L. (2012). Structural modeling of the institutional environment of the innovation cluster. MIR: Modernization. Innovation. Development, 4(12), 40-45.

Odyagailo, B. M. (2006). Genesis and Globalization Adaptability of the Economic System (Institutional Approach). Lviv: Magnolia plus.

OECDReviews of Innovation Policy.(2012). Retrievedfromhttp://www.keepeek. com/Digital-Asset-Management/oecd/science-and-technology/oecdreviews-of-innovation-policy-sweden-2012_9789264184893-en\#page7

OECD Science, Technology and Industry Outlook 2014. (2014). Retrieved from http://www.oecd-ilibrary.org/science-and-technology/oecd-sciencetechnology-and-industry-outlook-2014_sti_outlook-2014-en

Orev, I. (2011). Innovative development of the Western region. NEWS CSSTU. Business Issue, 8 July, 6-8.

Owen-Smith, J., \& Powell, W. W. (2004). Knowledge networks as channels and conduits: The effects of spill-overs in the Boston biotechnology community. Organization Science, 15, 5-21.

Panyushkin, S. V. (2011). Assessment of the market's performance of the functions of promoting innovation and redistribution in Russian economy. Innovations, 6(152), 58-66.

Perroux, F. (1950). Economic space: Theory and applications. Quarterly Journal of Economics, 64, 89-104.

Perroux, F. (1967). Note sur la ville consideree comme pole de developpement et comme foyer du progress. Revue Tiers-Monde, 8(32), 1147-1158.

Pishulin, O. (2020). Digital economy: trends, risks and social determinants. Razumkov Center. Testament Publishing House. Kyiv. Retrieved from https://razumkov.org.ua/uploads/article/2020_digitalization.pdf

Porter, M. E. (2005). Competition. Kyiv: Williams.

Prigochin, I., \& Stengers, I. (2005). Order from Chaos. Moscow: Komkniga.

Rallet, A., \& Torre, A. (2001). Proximité géographique ou proximité organisationnelle? Une analyse spatiale des coopérations technologiques dans les réseaux localisés d'innovation. Economie Appliquée, 1, 147-171. 
Ratner, S. V., \& Karlov, A. V. (2011). Mechanisms for implementing the network model of business incubation. Innovations, 7(153), 11-15.

Redina, N. I., Paderin, I. D., \& Polevaya, L. M. (2009). Synergetic effect of the planning system of an industrial enterprise. Bulletin of Economic Science of Ukraine, 1, 155-163.

Richardson, H. W. (1973). Theory of the distribution of city sizes: Review and prospects. Regional Studies, 7, 239-251.

Richardson, H. W. (1974). Agglomeration potential: A generalization of the income potential concept. Journal of Regional Science, 14, 325-336.

Sabluk, P. T., \& Kropyvko, M. F. (2010). Clustering as a mechanism for increasing the competitiveness and social orientation of the agricultural economy. Economics of Agro-Industrial Complex, 1, 3-12.

Spilling, O. R. (2006). Entrepreneurship in an evolutionary perspective - on entrepreneurship as a diversity increasing and reducing mechanism. Nordic Conference on Small Business Research, Stockholm. Retrieved from http://www.ncsb2006.se/pdf/Entrepreneurship\%20Evolutionary\%20Pers

Tarasova, O. (2007). Determining the sectoral orientation of the region with the help of clusters. Reports of the International Conference "Scientific Thought of the Information Age." Dnepropetrovsk: Science and Education.

Tatarkin, A. I. (2011). Modernization as a need for the socio-economic development of Russia. Zauralsky scientific bulletin, 1, 7-23.

Tishchenko, O. M. (2010). Clusters as a vector of economic development: Organization, essence and concept. Theoretical and Applied Issues of Economics, 21, 74-80. Retrieved from http://tppe.econom.univ.kiev.ua/ data/2010_21/Zb21_10.pdf

Togunov, I. A. (2009). New in the Theory of Organization: Fractal-Facet Models. Vladimir: Cathedral.

Tolstykh, T. O., \& Asnina, N. G. (2009). Formation of an innovative strategy for the development of an economic cluster. Bulletin of the Russian State Trade and Economic University, 7, 81-87.

Trifilova, A. A. (2008). "Open innovations" paradigm of modern innovative management. Innovations, 1(111), 73-77.

Usov, L. S. (2009). Research of entropy as a tool for analyzing and forecasting the effectiveness of innovation (concept). Innovation, 38-43.

Vlasenko, V. (2015). In search of Silicon Valley: How the state develops innovative hubs. Retrieved from http://www. althoughda.com.ua/ publications/2015/08/12/554568/

Winter, S. G. (1984). Schumpeterian competition in alternative technological regimes. Journal of Economic Behaviour and Organization, 5, 287-320.

Zaremskyi, B. V. (2010). Cluster strategy of innovative development of regions in the context of the global economy. Proceeding of the III International Scientific-Practical Conferences on Investment priorities of the era of globalization: the impact on the national economy and individual business (October 7-8, 2010). Retrieved from http://www.confcontact. com/20101008/2_zarem.htm 
Zhdanova, O. (2008). Cluster as a modern form of industrial enterprise management. Bulletin of the Institute of Economics of the Russian Academy of Sciences, 4, 264-271.

\begin{abstract}
Abstrakt
CEL: Ukazanie efektu synergii, będqqego rezultatem sieciowych interakcji instytucji rozwoju w nowej wirtualnej rzeczywistości gospodarczej oraz przedstawienie ogólnej charakterystyki ich relacji w kontekście funkcjonowania klastrów ery cyfryzacji gospodarki, której rezultatem sq produkty/usługi cyfrowe i różne platformy. METODYKA: W oparciu o metody dialektyczne, systemowe i macierzowe oraz z wykorzystaniem podejścia instytucjonalno-sieciowego badane sq charakterystyczne cechy oddziaływań sieciowych formacji klastrowych w warunkach wirtualnej rzeczywistości, które stajq się dziś normq. Metodę porównawczq stosuje się w zakresie warunków tworzenia klastra innowacyjno-cyfrowego z punktu widzenia teorii instytucjonalnej. WYNIKI: Współpraca sieciowa w warunkach wirtualnej rzeczywistości wykazuje efekty synergiczne poprzez nowe formy akumulacji jakościowej i wzrost nowej wiedzy, który następuje poprzez ich sieciowq replikację (podział), a wzrost innowacyjny jest wynikiem kształtowania się w gospodarce i społeczeństwie nowego, sieciowego modelu koordynacji połqczeń, nowej jakości współpracy sieciowej, na bieżq̨co dostosowywanej przez narzędzia cyfrowe. Synergiczny efekt tworzenia sieci tworzy nowe zjawisko rosnq̨cej użyteczności krańcowej i rosnqcej produktywności krańcowej wynikajqcej z innowacyjnej glokalizacji i cyfrowej globalizacji. Im większa skala innowacji i działań cyfrowych w warunkach wirtualnej rzeczywistości, tym większa efektywność wykorzystania dodatkowych zasobów. Efekt skali jest szczególnie widoczny w sieci, która korzysta z produkowanych i testowanych przez niq standardów. IMPLIKACJE DLA
\end{abstract} TEORII I PRAKTYKI: Udowodniono, że podejście synergiczne stosowane $w$ tworzeniu i rozwoju klastrów innowacyjno-cyfrowych rozpatrywane jest przez pryzmat relacji "relacja podmiotowo - podmiotowa organizacji aktywnych innowacyjnie i przedsiębiorstw cyfrowych". Dodatkowo w naszym przypadku efekt ten leży na płaszczyźnie restrukturyzacji "starych" instytucji rozwoju w "nowe”, pod wpływem odpowiednich podstaw instytucjonalno-prawnych, systemowej i kompleksowej modernizacji i dywersyfikacji wszystkich sektorów produkcji, poprawy sytuacji innowacyjnej i inwestycyjnej, budowy efektywnej, innowacyjnej i cyfrowej infrastruktury wirtualno-rzeczywistej na poziomie europejskim, wdrożenie klastrowania gospodarki z wykorzystaniem możliwości współpracy sieciowej. ORYGINALNOŚć I WARTOŚć: Ujawnia się interakcja formacji klastrowych w oferowanych przez autorów warunkach wirtualnej rzeczywistości; podana jest wizja autorów, jej elementów strukturalnych, jak z rozszerzonej sieci cyfrowej i wirtualnej rzeczywistości społeczno-gospodarczej; badana jest taksonomia i kategoryzacja terminologii, za pomoca której można ukazać kształtowanie się współpracy sieciowej w warunkach wirtualnej rzeczywistości i jej dalszy rozwój. Na podstawie przeprowadzonej głębokiej analizy teoretyczno-metodologicznej oraz prezentacji retrospektywy zmian innowacyjnych i cyfrowych, pokazano stopniowa transformację formacji klastrowych. Podstawa gospodarki sieciowej sq instytucje sieciowe, podmioty, organizacje, ponadto środowisko, w którym każdy 
biznes, podmiot lub osoba, która, bez względu na to, gdzie znajduje się w systemie gospodarczym, była w stanie łatwo i przy minimalnych kosztach komunikować się z jakqkolwiek innq firmq lub osobq na temat współpracy, kwestii handlowych lub know-how, lub po prostu dla zabawy w warunki nowej wirtualnej rzeczywistości.

Słowa kluczowe: rzeczywistość wirtualna, gospodarka sieciowa, współpraca sieciowa, tworzenie klastrów, rzeczywistość rozszerzona, efekty synergii, cyfryzacja gospodarki, struktury sieciowe klastrów, jakość połqczeń sieciowych

\section{Biographical notes}

Kraus Kateryna, Ph.D. (Economics), is Associate Professor, Docent of the Department of Management Borys Grinchenko Kyiv University. The title of her candidate's dissertation thesis is "Marketing management of small commercial enterprises." She is an author of 150 scientific and methodological works, among them 4 monographs and 2 dictionaries. Her scientific interests are the development of the innovative business hub, innovative developments in the higher education sector, teaching digital entrepreneurship, and development of digital competencies. She is a participant of the international grant project under the program KEY ACTION 2: Cooperation for innovation and the exchange of goods "Teaching Digital Entrepreneurship".

Kraus Nataliia, Dr. Sc. (Economics), is Associate Professor, Professor of the Department of Finance and Economics, Borys Grinchenko Kyiv University. She is an author of 260 scientific and methodological works, among them 8 monographs and 2 dictionaries. Her scientific interests are the digitalization of the economy through the prism of new industrialization, the institutional basis for the formation of an innovative economy in a globalized world and the trajectory of its development, the legalization of the shadow economy and its impact on the economic security of society and state. The field of research is the issue of providing high-quality educational services in the context of the latest professions, digital competences and the content of digital technologies in education; innovative entrepreneurial models of modern universities, global trends in the strategy of innovative universities, key risks, and new opportunities. She is a participant in the international grant project under the program KEY ACTION 2: Cooperation for innovation and the exchange of goods "Teaching Digital Entrepreneurship."

Shtepa Olena, Ph.D. (Economics), is Associate Professor, Senior Lecturer of the Department of Management, Borys Grinchenko Kyiv University. Her interests are scientific interests: management education, functioning of the banking system, project management, Scientific interests: programs and projects in international cooperation, Interests, and hobbies: tennis, skiing, travel, 
scientific activities. She is a participant of the international scientific and educational projects: the program KEY ACTION 2: Cooperation for innovation and the exchange of goods "Teaching Digital Entrepreneurship"; "Modern University - the project approach to the organization of work in accordance with the provisions of the European Qualifications Framework"; "European Qualifications Framework (ERK) and tools for their implementation in the program Horyzont 2020."

\section{Conflicts of interest}

The authors declare no conflict of interest.

\section{Citation}

Kraus, K., Kraus, N., \& Shtepa, O. (2021). Synergetic effects of network interconnections in the conditions of virtual reality. Journal of Entrepreneurship, Management and Innovation, 17(3), 149-188. https://doi. org/10.7341/20211735 